${ }^{1}$ Res. Assist. Dr., Akdeniz University, Antalya, Turkey, buyukdagnaci@gmail.com

ORCID: 0000-0002-9836-5942

Submitted: 5/08/2021

Revised: 15/09/2021

Accepted: 1/10/2021

Online Published: 25/12/2021

Citation: Büyükdağ, N., The effect of brand awareness, brand image, satisfaction, brand loyalty and WOM on purchase intention: An empirical research on social media, bmij (2021) 9 (4): 13801398, doi:

https://doi.org/10.15295/bmij.v9i4.1902

\section{The effect of brand awareness, brand image, satisfaction, brand loyalty and WOM on purchase intention: An empirical research on social media}

\author{
Marka farkındalığı, marka imajı, marka tatmini, marka sadakati ve \\ ağızdan ağıza iletişimin satın alma niyeti üzerindeki etkisi: Sosyal \\ medya üzerine ampirik bir araştırma
}

\author{
Naci Büyükdağ ${ }^{1}$
}

\begin{abstract}
The purpose of this study is to propose a model to understand the impact of brand information (awareness and image) on marketing variables (satisfaction, brand loyalty, WOM and purchase intention) for individuals who like or follow brands in social media. In this study, 522 questionnaires were collected, and multi-group structural equation modelling was used. According to the findings, brand awareness had a significant direct effect on brand image and a significant indirect effect on brand loyalty and purchase intention through brand image. Also, the immediate effects of brand image on satisfaction, brand loyalty, and purchase intention were significant, and the indirect effect of brand image on WOM and purchase intent through brand loyalty is substantial. Thus, brand awareness and brand image have become prominent variables in terms of brand loyalty, WOM, and consumers' purchase intentions in social media. It has been determined that brand loyalty is crucial for brands in social media. Although brand loyalty has a low explained variance rate, its impact on WOM and purchase intention is robust. Social media has also been shown to affect WOM and purchase intention substantially. Also, using the theory of gender socialization examines whether the whole model changes according to gender. Finally, managerial and theoretical implications, limitations and recommendations are presented.
\end{abstract}

Keywords: Brand Awareness; Brand Image, Brand Satisfaction, Brand Loyalty, WOM, Purchase Intention, Gender

JEL Codes: M30, M31, M37

Öz

$\mathrm{Bu}$ çalışmanın amacı, sosyal medyada markaları takip eden bireyler açısından marka bilgisinin (farkındalık ve imaj) pazarlama değişkenleri (tatmin, marka sadakati, WOM ve satın alma niyeti) üzerindeki etkisini anlamaya yönelik bir model önerisi sunmaktır. Bu çalışmada 522 anket toplanmış ve çok gruplu yapısal eşitlik modellemesi kullanılmıştır. Elde edilen bulgulara göre, marka farkındalığı marka imajı üzerinde doğrudan anlamlı bir etkiye sahipken, marka imajı aracılığıyla marka sadakati ve satın alma niyeti üzerinde de anlamlı bir dolaylı etkiye sahiptir. Ayrıca, marka imajının marka sadakati ve satın alma niyeti üzerinde doğrudan anlamlı bir etkisi bulunmakla birlikte, marka sadakati aracılığıyla da WOM ve satın alma niyeti üzerinde de anlamlı etkilere sahiptir. Bundan dolayı, marka farkındalığı ve marka imajı, sosyal medyayı kullanan tüketicilerin marka sadakatleri, WOM'ları ve satın alma niyetleri açısından öne çıkan değişkenlerdir. Sosyal medya da marka sadakatinin de önemli olduğu tespit edilmiştir. Marka sadakatinin açıklanan varyans oranı düşük olmasına rağmen, WOM ve satın alma niyeti üzerindeki etkisi güçlüdür. Sosyal medyanın WOM ve satın alma niyeti üzerindeki etkisinin önemli olduğu gösterilmiştir. Ayrıca, cinsiyet sosyalleşme teorisi baz alınarak cinsiyetin tüm modele göre değişiklik gösterip göstermediği de incelenmiştir. Yönetimsel ve teorik çıkarımlar, sınırlılıklar ve geleceğe yönelik öneriler sunulmuştur.

Anahtar Kelimeler: Marka Farkındalığı, Marka İmajı, Marka Tatmini, Marka Sadakati, WOM, Satınalma Niyeti, Cinsiyet

JEL Kodlari: M30, M31, M37 


\section{Introduction}

Internet technology, one of the most important inventions of the 20th century, has significantly changed the communication and lifestyle of people (cited by Yan, Qiang, Wu, Wang, Wu, Chen, and Wei., 2016: 62). Also, with the spread of internet technology, the use of social media among people has increased, and the socialization of consumers has made significant progress (Chu \& Sung, 2015: 252). Therefore, social media has become one of the most critical interactions between people (Shanahan, Tyler, Tran, and Taylor, 2019: 57). According to the Digital 2020 report, approximately $67 \%$ of the world's population uses the internet, and 49\% actively used social media in 2020. Compared to 2020 and 2019, the rate of internet users increased by $2.4 \%$, and the rate of active social media users increased by $9.2 \%$ in 2020 (Digital 2020 Report). According to this situation, individuals who were not social media users have started to use social media in the future because the increase in social media users is higher than the increase in the rate of internet users. Naturally, we anticipate that social media may become more critical for all stakeholders in the future because consumers trust the information that got from social media during the decision-making process (Barreda, Bilgihan, Nusair \& Okumus, 2015).

According to Ahmad \& Laroche (2017: 202), 97\% of consumers read comments and are affected by these. Therefore, the presence of social media significantly affects and increases social media-based marketing activities of businesses (Habibi, Laroche \& Richard, 2014: 152; Tran \& Strutton, 2020:1) because social media has become an important centre and a dominant digital communication channel in terms of accessing and sharing information and transferring experiences to other consumers (Hudson, Huang, Roth \& Madden, 2016: 27; Siqueira, Peña, ter Horst \& Molina, 2019: 1). Besides, consumers use social networking sites to purchase products or services and receive information, advice and feedback from their social environment (Lee \& Choi, 2019: 9). As a result, consumers' activities on social media can affect consumers' purchasing intentions (Siqueira et al., 2019:1) which is a sufficient reason for retailers, brands or businesses to move their products or services to the social media environment (Baum, Spann, Füller and Thürridl, 2019: 289).

According to Baum et al. (2019), promoting marketing in social media channels can significantly contribute to reaching too many people in a short time and affecting customers' decision-making processes and purchasing intentions due to the trust created by the social media environment in consumers. Also, although social media does not require significant investments (cited by Hew, Lee, Ooi, \& Lin, 2016: 142), it allows businesses to interact with millions of customers simultaneously (cited by Hew et al., 2016: 142; Shanahan et al., 2019: 57; Mangold \& Faulds, 2009: 357). Furthermore, social media can increase its market share and sales with low-cost advertisements (Kim, Koh, YCha, \& Lee, 2015: 40). According to the study by Büyükdağ, Kaya \& Kitapci (2019), marketing-related expenditures increase the profitability of companies and profit per share.

Social media channels play a facilitating role in the relationship between business/brand and consumers, integrate dimensions regarding consumers' buying, provide more information about product selection, and establish a stronger buyer-seller relationship ( $\mathrm{Wu}, 2016$; Agnihotri, Dingus, $\mathrm{Hu}$ \& Krush, 2013: 172). Thus, businesses are sent to consumers to "like" the company on Facebook, to follow the company on Twitter or to "connect" through the LinkedIn channel (Agnihotri et al., 2013: 172). Consumers can follow/like/connect the brands or businesses they like in response to requests from companies or brands. The critical question here is determining the factors that cause consumers to follow and like brands. This study, it is aimed to estimate how the relationships between brand awareness, brand image, customer satisfaction, brand loyalty, word of mouth communication and purchase intention have been determined for consumers who follow brands on social media because according to Laroche et al. (2013: 76), social media are used to connect consumers. In this case, how the relations between the brand and consumers in social media developed has remained unsolved. Also, according to Laroche, Habibi \& Richard. (2013), most studies on social media and marketing do not investigate the effects of brand-related variables on marketing variables. Therefore, it is critical and necessary to examine the impact of the variables related to the brand used in social media on marketing variables (Laroche et al., 2013: 76) because brands are the most valuable assets of businesses (Gensler, Völckner, Liu-Thompkins, Wiertz, 2013: 242; Kim, Junghun, Lee \& Lee, 2020: 2; Sääksjärvi \& Samiee, 2011: 169). Therefore, one of the primary targets of managers is to create a strong brand by generating bright and vibrant information about the brand in consumers' minds (Gensler et al., 2013: 242). According to Popp and Wilson (2018: 141), social media channels have substantial effects on the recall of brands in the consumer mind. Therefore, all brands in any category interact with their consumers through social media (Coelho, Rita \& Santos, 2018: 101). For this purpose, businesses have increased their spending budgets on social media by 250\% over the past ten years (Shanahan et al., 2019: 57). 
As a result, the model will provide businesses with helpful information on pursuing the social media platform and add value to the literature and stakeholders. Also, according to gender socialization theory, males and females have diversified values and psychological characters, and gender affects individuals' decisions, beliefs and attitudes (Büyükdağ, Soysal \& Kitapci, 2020: 9; Calabrese, Costa \& Rosati, 2016: 136; Vicente-Molina, Fernández-Sainz \& Izagirre-Olaizola, 2018: 91). Therefore, this study also analyzed whether gender differed in terms of the paths in the proposed model.

In the first part of the study, information about the variables used in the model is given. Then, causal relationships between the variables are established. In the second part, CFA and path analysis was applied. Finally, in the third part, discussion, results, managerial and theoretical implications, limitations, and future suggestions are given.

\section{Theoretical background and hypothesis}

\section{Brand awareness}

Brand awareness is the first step to obtaining information about the brand (Barreda, Bilgihan, Nusair \& Okumus, 2016: 183). Brand awareness includes two main elements: brand recall and brand recognition (Kotler and Keller, 2008). Brand recall is defined as correctly creating or bringing back the brand in the consumers' memories. Brand recognition is indicated as the brand's differentiation in the different brand options of the consumers (Foroudi, Jin, Gupta, Foroudi \& Kitchen, 2018: 464). Brand awareness is a necessary element for the starting of the communication process (Barreda et al., 2015: 601), and it is shaped and controlled by the advertising and promotion activities created by the corporates (Sürücü, Öztürk, Okumus \& Bilgihan, 2019: 115). Brand awareness has an impact on consumers' preferences and decision-making process for buying (Barreda et., 2015: 600-601), prediction of purchasing behaviour (Lee, 2014: 1245), the motivation of the brand perception, attitudes and preferences (Lee, 2014: 12441245) and brand commitment and loyalty (cited by Kim, Choe \& Petrick, 2018: 321). Also, according to the literature, brand awareness has a significant impact on the brand image (Barreda et al., 2016; Martínez, Montaner \& Pina, 2009) and brand loyalty (Kim, Choe \& Petrick, 2018; Torres, Augusto \& Lisboa, 2015). Therefore, the following hypotheses have been established.

$\mathrm{H}_{1}$ : Brand image is significantly affected by brand awareness.

$\mathrm{H}_{2}$ : Brand loyalty is significantly affected by brand awareness.

\section{Brand image}

Brand image is one of the components that increase the efficiency of marketing communication and create brand information (Keller, 1993: 9). According to Keller (1993: 3), the brand image consists of the brand associations of types, favorability, strength and uniqueness (Keller, 1993: 3). In terms of brand management literature, a positive, solid, and unique brand image can create a sustainable competitive advantage by providing attractive economic returns (Persson, 2010: 1269). The brand image includes beliefs, perceptions, feelings and attitudes regarding the psychological structure of consumers, and consumers prefer brands or products through the brand image (cited by Song, Wang \& Han, 2019: 51). Also, brand image is one of the crucial elements affecting consumers' decision making and consumer satisfaction (Song et al., 2019: 51). Social media communication also powerfully affects the brand image (Godey, Manthiou, Pederzoli, Rokka, Aiello, Donvito \& Singh, 2016: 5835). According to the literature, brand image has a substantial impact on customer satisfaction (Song et al., 2019; Wai Lai, 2019), brand loyalty (Kim et al., 2018; Cretu \& Brodie, 2007: 233; Mody, Day, Sydnor, Lehto \& Jaffé, 2017; Martínez et al., 2009) and purchase intention (Lee, 2014: 1245). Therefore, the following hypotheses have been established.

\section{$\boldsymbol{H}_{3}$ : Customer satisfaction is significantly affected by brand image. \\ $\boldsymbol{H}_{4}:$ Brand loyalty is significantly affected by brand image. \\ $\boldsymbol{H}_{5}$ : Purchase intention is significantly affected by brand image.}

\section{Satisfaction}

Customer satisfaction is one of the critical structures used to explain consumer behaviour (Konuk, 2019: 105). Satisfaction affects customers behavioural and attitudinal loyalty after consumption, and satisfied customers are less sensitive to price, more strongly protected from competitors' attacks, and are considered more loyal than dissatisfied customers (cited by Nam, Ekinci \& Whyatt, 2011: 1009). Satisfied customers generally continue to use or buy the product (cited by Verkijika \& De Wet, 2019: 222) and have positive attitudes towards the products (Verkijika \& De Wet, 2019: 222). Customer satisfaction is explained as consumers' emotional responses regarding the comparison between product performance 
and customer expectations (Gamboa \& Gonçalves, 2014: 713). According to the literature, customer satisfaction significantly affects brand loyalty (Nam et al., 2011; Song et al., 2019; Hew et al., 2016; Cheng, Wu \& Chen, 2018; Han, Nguyen, Song, Chua, Lee \& Kim, 2018; Pereira, Salgueiro \& Rita, 2016; Gamboa \& Gonçalves, 2014: 715), WOM (Verkijika \& De Wet, 2019; Konuk, 2019; Ranaweera \& Jayawardhena, 2014) and purchase intention (Bai, Law \& Wen, 2008; Gamboa \& Gonçalves, 2014: 713). Therefore, the following hypotheses have been established.

$H_{6}$ : Brand loyalty is significantly affected by customer satisfaction.

$\mathrm{H}_{7}:$ WOM is significantly affected by customer satisfaction.

$H_{8}$ : Purchase intention is significantly affected by customer satisfaction.

\section{Brand loyalty}

Loyalty is one of the primary impulses of profitability because it provides a cost advantage by holding the loyal customers of the companies, and it gives more intention to purchase and less price sensitivity (Popp \& Wilson, 2018: 143). Therefore, loyalty is a vital strategy and a requirement for businesses online (Demangeot \& Broderick, 2010: 167). Loyalty is also a strategic strength for retailers to compete in a fierce competition environment (Kwon \& Lennon, 2009: 559). Loyalty consists of behavioural and attitudinal loyalty. Behavioural loyalty refers to the oftenness of repurchase, while behavioural loyalty refers to dedication to a product's purchasing actions such as purchase intention and recommendation intention (Nam et al., 2011: 1015; cited by Hew et al., 2016: 144). According to the literature, brand loyalty significantly affects purchase intention (Kim \& Lee, 2019; Das, 2014a; Huang \& Chen, 2018; Anderson et al., 2014; Kim \& Lee, 2019; Munnukka et al., 2015) and WOM (Eelen et al., 2017; Munnukka Karjaluoto \& Tikkanen, 2015; Huang \& Chen, 2018). Therefore, the following hypotheses have been established.

$\boldsymbol{H}_{9}$ : WOM is significantly affected by brand loyalty.

$\mathrm{H}_{10}$ : Purchase intention is significantly affected by brand loyalty.

\section{Word of mouth (WOM)}

WOM is an effective instrument in marketing ( $\mathrm{O}^{\prime}$ Cass \& Carlson, 2012: 30). The commitment and positive emotions shape WOM behaviour (cited by Seo \& Park, 2018: 37; cited by Siqueira et al., 2019: 2).WOM is defined as informal communicating between consumers about the product or service (Liu, 2006: 74). This communication actively promotes consumers to other potential customers and affects purchase intention (Feng \& Papatla, 2011: 75). Also, according to Berger (2014), e-WOM creates more than 3 billion brand impressions daily through communication channels such as social media (cited by Wakefield \& Bennett, 2018: 148). Therefore, WOM is a very active communication channel and provides social and psychological benefits to consumers (Park, Lee \& Borle, 2018: 304). According to the literature, Wom substantially impacts purchase intention (Chiu, Liu \& Tu, 2016; Tajvidi \& Karami, 2017: 1). Thus, the following hypotheses have been established.

$\boldsymbol{H}_{11}$ : Purchase intention is significantly affected by WOM.

\section{Purchase intention}

Understanding and increasing the consumers' purchase intentions is vital in terms of raising the probability of purchasing because the purchase intention is one of the antecedents of the actual purchasing behaviour and is an essential indicator in predicting consumer (Hsu, Chang \& Yansritakul, 2017: 145; Martins, Costa, Oliveira, Gonçalves \& Branco, 2019: 379; Wu, Yeh \& Hsiao, 2011: 32; cited by Bachleda, Fakhar \& Elouazzani, 2016: 294). Purchase intention is a composition of consumers' concern and the likelihood of purchasing the product and refers to an attempt to buy the product in the coming periods through its attitude and preferences (Kim \& Ko, 2012: 1481; cited by Das, 2014: 408).

\section{Indirect effect in the model}

$\mathrm{H}_{1}$ and $\mathrm{H}_{11}$ hypotheses were established in the model. Also, it is possible to examine the indirect effects of the variables involved in the model as a mediator. Because the mediator variables, which are among the independent and dependent variables, can ensure that the independent variable has an indirect impact on the dependent variable. For example, according to the $\mathrm{H}_{1}$ hypothesis, brand awareness affects brand image. Also, according to the $\mathrm{H}_{4}$ hypothesis, brand image affects brand loyalty. As a result, brand awareness is likely to indirectly impact brand loyalty through brand image. For this reason, the following hypotheses have been created by considering the mediating variables in the model.

$\boldsymbol{H}_{12 a}$ : Customer satisfaction is indirectly affected by brand awareness through brand image.

$\boldsymbol{H}_{12 b}$ : Brand loyalty is indirectly affected by brand awareness through brand image. 
$H_{12 c}$ : Purchase intention is indirectly affected by brand awareness through brand image.

$H_{12 d}$ : Brand loyalty is indirectly affected by brand image through customer satisfaction.

$\boldsymbol{H}_{122}:$ WOM is indirectly affected by brand image through customer satisfaction.

$\boldsymbol{H}_{12 f}$. Purchase intention is indirectly affected by brand image through customer satisfaction.

$\boldsymbol{H}_{12 g}:$ WOM is indirectly affected by brand image through brand loyalty.

$\boldsymbol{H}_{12 h}$ : Purchase intention is indirectly affected by brand image through brand loyalty.

$\boldsymbol{H}_{12 i}:$ WOM is indirectly affected by brand awareness through brand loyalty.

$\boldsymbol{H}_{12 j}:$ Purchase intention is indirectly affected by brand awareness through brand loyalty.

$H_{12 k}$ : WOM is indirectly affected by customer satisfaction through brand loyalty.

$\mathrm{H}_{122}$ : Purchase intention is indirectly affected by customer satisfaction through brand loyalty.

$\boldsymbol{H}_{12 m}$ : Purchase intention is indirectly affected by customer satisfaction through WOM.

$H_{12 n}$ : Purchase intention is indirectly affected by brand loyalty through WOM.

\section{The moderating role of gender}

Gender is a crucial socio-demographic variable shaped by institutional and social norms, continually changing as a result of daily interactions and practices, and is powerfully explained by culture and society compared to biology and nature (Mortimer and Clarke 2011: 576; Kim, Cho \& Kim, 2019: 214). Also, gender impacts attitudes, beliefs, ideas, and behaviours and shows substantial differences in consumers' anticipations (Vicente-Molina et al., 2018; Büyükdağ et al., 2020: 3; Sreen, Purbey \& Sadarangani, 2018; Calabrese et al., 2016). Gender has a significant effect on understanding consumers' behaviour and individuals' decisions (Han, Yu \& Kim, 2019: 87; Kwun, 2011: 252) and is influenced by culture (Tifferet \& Vilnai-Yavetz, 2014). Besides, it appears as an essential moderator variable in examining causal relationships (Vicente-Molina et al., 2018: 91). Gender Socialization Theory also states that gender can affect individuals' moral orientation, decision-making, and behavioural intentions since males and females have diversified values and psychological characteristics (Calabrese et al., 2016: 136). As a result, $\mathrm{H}_{1}-\mathrm{H}_{11}$ hypotheses were also analyzed in terms of gender. However, these hypotheses were reconsidered as $\mathbf{H}_{1 \mathrm{a}}-\ldots-\mathbf{H}_{11 \mathrm{a}}$ for females and $\mathbf{H}_{1 \mathrm{~b}}-\ldots-\mathbf{H}_{11 \mathrm{~b}}$ for males. As a result, the research model in Figure 1 has been created and analyzed.

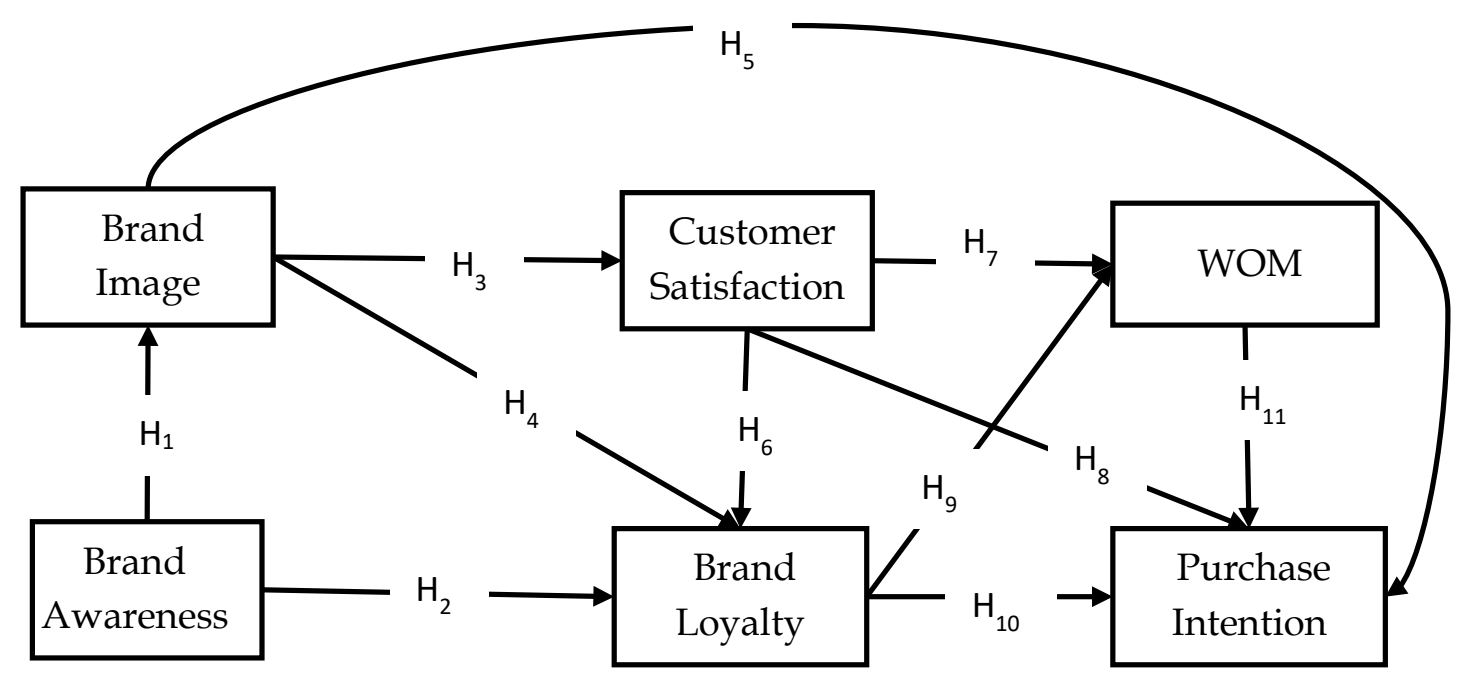

Figure 1: Research Model

Note: The moderator effect of gender was examined in terms of all paths in the model.

\section{Methodology}

\section{Data collection}

The study's target audience consists of consumers who follow the brands from social media aged 18 and over. The purpose of this is to select consumers who use social media for entertainment and consumers who follow brands and are the potential target audience of brands. As the sampling method, the convenience sampling method was used. As a result, 661 questionnaires were collected from the target 
audience. However, 522 valid questionnaires were made suitable for the analysis to eliminate the missing data. During the data collection process, no incentives were given to the participants, and the attendees participated in the survey voluntarily. Since the data were collected before 2020, ethics committee approval is not required, and ethics committee approval was not obtained.

\section{Measures}

The constructs were measured using five-point, Likert-type, multiple-item scales anchored with "Strongly Disagree" (1) and "Strongly Agree" (5). The constructs in this study were measured by existing scales used in the literature of consumer behaviour and adapted to the context of this study. The brand loyalty scale has been obtained and adapted from the study conducted by Chen (2012), Lin, Lobo \& Leckie (2017), Laroche et al. ( 2013) and Nam et al. (2011). The word of mouth (WOM) scale has been obtained and adapted from the study conducted by Kudeshia, Sikdar \& Mittal (2016). The brand awareness scale has got and adapted from the research undertaken by Lu, Gursoy \& Lu (2015), and the brand image scale has been obtained and adapted from the study by Lien, Wen, Huang \& Wu (2015). The satisfaction scale about the brand on social media has been accepted and adapted from the research conducted by Abzari, Ghassemi \& Vosta (2014) and Tsiros, Mittal \& Ross (2004). Finally, the purchase intention scale has been obtained and adapted from the study conducted by Erkan and Evans (2016).

\section{Data analysis and results}

\section{Measurement model}

Structural equation modelling is a method that tests the compatibility of the theoretically constructed model to reality and simultaneously analyzes the causal relationships between variables (Hair et al., 2014: 542-553). Therefore, confirmatory factor analysis (CFA) was applied in this study and path analysis was continued after the fit indexes were evaluated in terms of the threshold value. The number of items used in the model is 23. After CFA analysis, 1 item was removed from the brand image, and 1 item from WOM and the theoretical model was measured with 21 items. Regarding this analysis; chisquare/df value was 2.386 , CFI value was 0.95 , SRMR value was 0.048 , RMSEA value was 0.052 , GFI value was 0,93, AGFI value was 0,90 and p Close value was 0.333. According to Hu \& Bentler (1999), the fit index values of the model are above the threshold values and represent the perfect fit between theory and reality. Measurements and results of Confirmatory Factor Analysis are given in Table 1. 
Table 1: Confirmatory Factor Analysis Results

\begin{tabular}{|c|c|c|}
\hline \multicolumn{2}{|c|}{ Latent and Observed Variables } & $\begin{array}{l}\text { Factor } \\
\text { Loading }\end{array}$ \\
\hline \multicolumn{3}{|c|}{ Brand Awareness $\rightarrow$ Composite Reliability:0.792; AVE:0.559 } \\
\hline BA1 & I can quickly recall the symbol or logo of the brand I follow on social media & ,696*** \\
\hline BA2 & I am aware of the brand I follow on social media &, $796 * * *$ \\
\hline BA3 & I can recognize the brand I follow on social media among other competing rivals. & ,748*** \\
\hline \multicolumn{3}{|c|}{ Brand Image $\rightarrow$ Composite Reliability:0.822; AVE:0.536 } \\
\hline BI1 & The brand I follow on social media is reliable & ,742*** \\
\hline $\mathrm{BI} 2$ & The brand I follow on social media is attractive & ,772 *** \\
\hline $\mathrm{BI} 3$ & The brand I follow on social media is pleasing & $738 * * *$ \\
\hline BI5 & The brand I follow on social media has a good reputation & $674 * * *$ \\
\hline \multicolumn{3}{|c|}{ Brand Satisfaction $\rightarrow$ Composite Reliability:0.77; AVE:0.532 } \\
\hline SAT1 & I am satisfied with received information from other customers about this brand in social media & ,763*** \\
\hline SAT2 & Information received from other customers in social media has met my expectations. &, $817 * * *$ \\
\hline SAT3 & $\begin{array}{l}\text { Compared to other received information from other sources, the received information in social } \\
\text { media about the brand is acceptable. }\end{array}$ &, $589 * * *$ \\
\hline
\end{tabular}

\section{Brand Loyalty $\rightarrow$ Composite Reliability:0.813; AVE:0.524}

LOY1 I consider myself to be loyal to the brand I follow on social media ,678 ***

LOY2 I buy the brand I follow on social media regularly. 614 ***

LOY3 I will recommend the brand I follow on social media to someone who seeks my advice ,787 ***

LOY4 I will recommend the brand I follow on social media to other people ,799***

\begin{tabular}{|c|c|c|}
\hline \multicolumn{3}{|c|}{ Word of Mouth $\rightarrow$ Composite Reliability:0.766; AVE:0.522 } \\
\hline WOM1 & I often talk positively about the brand because I am following it on social media. & $692 * * *$ \\
\hline WOM2 & I recommend the brand that I follow on social media to friends and family & ,769*** \\
\hline WOM4 & I introduce the brand I follow on social media to other people & ,705*** \\
\hline \multicolumn{3}{|c|}{ Purchase Intention $\rightarrow$ Composite Reliability:0.843; AVE:574 } \\
\hline PI1 & I will likely buy the brand I follow on social media. & ,785 *** \\
\hline PI2 & I will purchase the brand I follow on social media next time I need a product. &, $800 * * *$ \\
\hline PI3 & I will definitely try the brand I follow on social media. & ,760*** \\
\hline PI4 & I will recommend the brand I follow on social media to my friends &, $681 * * *$ \\
\hline
\end{tabular}

Note: 1-BI4 and WOM3 were removed from the model resulting from CFA (BI4: The brand I follow on social media is a social status symbol WOM3: Information shared on the social media about the brand I follow influences my buying intentions) Note: $2-{ }^{* * *}<0.001,{ }^{* *} \mathrm{p}<0.01$ and ${ }^{*} \mathrm{p}<0.050$

The construct validity of all variables in the model is higher than 0.7 , and the reliability of the structures in the model is sufficient (Hair, Black, Babin, \& Anderson, 2014: 123-124). After this stage, the convergent and discriminant validity of the variables were examined. As a result, the correlation between structures and the square root of the average variance extracted values are given in Table 2.

Table 2: The Results of the Inter-Construct Correlations and Average Variance Extracted

\begin{tabular}{c|cccccc}
\hline & BA & BI & SAT & BL & WOM & PI \\
\hline BA & $\mathbf{0 , 7 4 8}$ & & & & & \\
BI & $0,567^{* * *}$ & $\mathbf{0 , 7 3 2}$ & & & & \\
SAT & $0,478^{* * *}$ & $0,434^{* * *}$ & $\mathbf{0 , 7 2 9}$ & & & \\
BL & $0,336^{* * *}$ & $0,344^{* * *}$ & $0,283^{* * *}$ & $\mathbf{0 , 7 2 4}$ & & \\
WOM & $0,425^{* * *}$ & $0,477^{* * *}$ & $0,381^{* * *}$ & $0,646^{* * *}$ & $\mathbf{0 , 7 2 3}$ & \\
PI & $0,321^{* * *}$ & $0,460^{* * *}$ & $0,355^{* * *}$ & $0,618^{* * *}$ & $0,591^{* * *}$ & $\mathbf{0 , 8 1 4}$ \\
\hline
\end{tabular}

Note: 1-Acronyms: $\mathbf{B A}=$ Brand Awareness; $\mathbf{B I}=$ Brand Image; SAT $=$ Satisfaction; $\mathbf{B L}=$ Brand Loyalty; WOM=Word of Mouth (WOM) PI:= Purchase Intention. $2-{ }^{* * *} p<0.001,{ }^{* *} p<0.01$ and ${ }^{*} p<0.0503$ - Bold values represent the square root of the AVE.

According to Table 2, convergent and discriminant validity is provided because the AVE value, the average of the squares of the factor loading of the structures, is more significant than 0.5 . Therefore, the AVE is larger than the correlation between the structures, or the AVE value is greater than the square of the correlation between the structures (Hair et al., 2014: 605; Fornell \& Larcker, 1981: 46). After this step, the common method bias (CMB) or standard method variance (CMV) analysis was performed.

Common method bias refers to the bias that an external factor causes in the dataset. A significant common method bias occurs when a single factor explains most of the variance (Podsakoff, MacKenzie, 
Lee \& Podsakoff, 2003; Gaskin \& Lim, 2016). Podsakoff et al. (2003) proposed various methods for testing common method bias. In this study, the single factor Harman test (this test is a weak test compared to other tests) and the method of controlling the effects of the directly measured latent methods factor has been applied. The explained variance of a single factor was $32 \%$ in the single factor Harman test. Also, controlling the effects of the directly measured latent methods factor, which is a more robust test, the explained variance rate is $30 \%$. As a result, since the explained variance rate does not express the majority, it can be said that common method bias does not have a significant effect.

\section{Structural model}

As a result of running the model; chi-square/df value was 2.632, CFI value was 0.94, SRMR value was 0.057, RMSEA value was 0.056, Pclose value was 0.055, GFI value was 0,92, and AGFI value was 0,90 . According to $\mathrm{Hu}$ and Bentler (1999), these values are acceptable and excellent values in terms of model fit, and it can be said that the model shows a good fit and significance. Regarding the model, it can be said that there is a perfect harmony between theory and reality. As a result, the coefficients for the model are given in Table 3 .

Table 3: Direct Effect Results of the Model

\begin{tabular}{|c|c|c|c|c|}
\hline Hypothesis & Independent Variable & Dependent Variable & $\begin{array}{l}\text { Coefficient of } \\
\text { Standardized }\end{array}$ & Conclusion \\
\hline $\mathbf{H}_{\mathbf{1}}$ & Brand Awareness & Brand Image &, $716 * * *$ & Supported \\
\hline $\mathbf{H}_{2}$ & Brand Awareness & Brand Loyalty & ,136 & Not Supported \\
\hline $\mathbf{H}_{3}$ & Brand Image & Customer Satisfaction &, $569 * * *$ & Supported \\
\hline $\mathbf{H}_{4}$ & Brand Image & Brand Loyalty & $349 * * *$ & Supported \\
\hline $\mathbf{H}_{5}$ & Brand Image & Purchase Intention &, $169 * *$ & Supported \\
\hline $\mathbf{H}_{6}$ & Customer Satisfaction & Brand Loyalty & ,079 & Not Supported \\
\hline $\mathbf{H}_{7}$ & Customer Satisfaction & WOM & $211 * * *$ & Supported \\
\hline $\mathrm{H}_{8}$ & Customer Satisfaction & Purchase Intention & ,061 & Not Supported \\
\hline $\mathrm{H}_{9}$ & Brand Loyalty & WOM &, $781 * * *$ & Supported \\
\hline $\mathrm{H}_{10}$ & Brand Loyalty & Purchase Intention & $602 * * *$ & Supported \\
\hline $\mathbf{H}_{11}$ & WOM & Purchase Intention & ,073 & Not Supported \\
\hline
\end{tabular}

According to Table 3, brand awareness on brand image is significant, but its effect on brand loyalty is not substantial. Brand image significantly affects satisfaction, brand loyalty, and purchase intention. On the other hand, customer satisfaction did not considerably affect brand loyalty and purchase intention, but it significantly affected WOM. Also, brand loyalty significantly affected both WOM and purchase intention. Finally, the impact of WOM on purchase intention is not significant. According to the model, the explained variance rate was approximately 51\% in brand image, 32\% in customer satisfaction, $25 \%$ in brand loyalty, $76 \%$ in WOM and $63 \%$ in purchase intention. In terms of variables in the model, the indirect effects of the independent variables on the dependent variable were also analysed and shown in Table 4. 
Table 4: Indirect Effect Results

\begin{tabular}{|c|c|c|c|c|c|c|c|c|}
\hline & Indir & ffect & ath & & & $\begin{array}{l}\text { Standardized } \\
\text { Coefficient }\end{array}$ & P-Value & Conclusion \\
\hline $\mathrm{H}_{12 \mathrm{a}}$ & BA & $\rightarrow$ & $\mathrm{BI}$ & $\rightarrow$ & SAT & 0,295 & 0,001 & Supported \\
\hline $\mathrm{H}_{12 \mathrm{~b}}$ & BA & $\rightarrow$ & $\mathrm{BI}$ & $\rightarrow$ & $\mathrm{BL}$ & 0,267 & 0,001 & Supported \\
\hline $\mathrm{H}_{12 \mathrm{c}}$ & BA & $\rightarrow$ & $\mathrm{BI}$ & $\rightarrow$ & PI & 0,102 & 0,003 & Supported \\
\hline $\mathbf{H}_{12 \mathrm{~d}}$ & BI & $\rightarrow$ & SAT & $\rightarrow$ & BL & 0,06 & 0,302 & Not Supported \\
\hline $\mathrm{H}_{12 \mathrm{e}}$ & BI & $\rightarrow$ & SAT & $\rightarrow$ & WOM & 0,139 & 0,002 & Supported \\
\hline $\mathrm{H}_{12 \mathrm{f}}$ & $\mathrm{BI}$ & $\rightarrow$ & SAT & $\rightarrow$ & PI & 0,037 & 0,359 & Not Supported \\
\hline $\mathbf{H}_{12 \mathrm{~g}}$ & $\mathrm{BI}$ & $\rightarrow$ & BL & $\rightarrow$ & WOM & 0,316 & 0,001 & Supported \\
\hline $\mathrm{H}_{12 \mathrm{~h}}$ & $\mathrm{BI}$ & $\rightarrow$ & BL & $\rightarrow$ & PI & 0,223 & 0,000 & Supported \\
\hline $\mathrm{H}_{12 \mathrm{i}}$ & $\mathrm{BA}$ & $\rightarrow$ & BL & $\rightarrow$ & WOM & 0,098 & 0,159 & Not Supported \\
\hline $\mathrm{H}_{12 \mathrm{i}}$ & $\mathrm{BA}$ & $\rightarrow$ & BL & $\rightarrow$ & PI & 0,069 & 0,126 & Not Supported \\
\hline $\mathrm{H}_{12 \mathrm{k}}$ & SAT & $\rightarrow$ & BL & $\rightarrow$ & WOM & 0,078 & 0,289 & Not Supported \\
\hline $\mathbf{H}_{121}$ & SAT & $\rightarrow$ & BL & $\rightarrow$ & PI & 0,055 & 0,262 & Not Supported \\
\hline $\mathrm{H}_{12 \mathrm{~m}}$ & SAT & $\rightarrow$ & WOM & $\rightarrow$ & PI & 0,018 & 0,604 & Not Supported \\
\hline $\mathrm{H}_{12 \mathrm{n}}$ & BL & $\rightarrow$ & WOM & $\rightarrow$ & PI & 0,045 & 0,608 & Not Supported \\
\hline
\end{tabular}

Note: 1-Acronyms: BA= Brand Awareness; BI= Brand Image; SAT= Satisfaction; BL= Brand Loyalty; WOM=Word of Mouth (WOM) PI:= Purchase Intention. $2-{ }^{* * *} p<0.001,{ }^{* *} p<0.01$ and ${ }^{*} p<0.0503$ 3- n.s.: not significant

According to Table 4, brand awareness indirectly affects satisfaction, brand loyalty and purchase intention if supported with the brand image. The brand image does not significantly affect brand loyalty and purchasing intention if supported with satisfaction, but it indirectly impacts WOM. Besides, if the brand image is backed with brand loyalty, it positively and indirectly affects WOM and purchases. However, the indirect impact of brand awareness and customer satisfaction on WOM and purchase intention through brand loyalty has been insignificant. Finally, the indirect effect of pride and brand loyalty on the purchase intention through WOM was also not significant.

\section{Multi-group structural equation modelling and analysis results}

Multi-group structural equation modelling shows whether the analysis results differ in sociodemographic variables and allows for a deeper analysis of the model. For example, in the study by Babin, Borges \& James (2016), how the structural model changes according to different cultures was examined. The study by Huang \& Ge (2019) examined how the structural model changes according to gender, education level, family status, and household vehicle ownership. While the study by Pappas, Pateli, Giannakos \& Chrissikopoulos (2014) examined how the structural model differentiated in terms of low and high experience, Murray, Elms \& Teller (2017) examined how the structural model differed in terms of old and new designs. As a result, the multi-group SEM analysis can better understand the model. The results are shown in Table 5. 
Table 5: Multi-Group SEM Results

\begin{tabular}{|c|c|c|c|}
\hline \multirow{2}{*}{\multicolumn{2}{|c|}{ Path }} & \multicolumn{2}{|c|}{ Gender } \\
\hline & & \multirow{2}{*}{$\begin{array}{l}\text { Female }(\mathrm{N}=261) \\
0,777^{* * *}\end{array}$} & \multirow{2}{*}{$\begin{array}{l}\text { Male }(\mathrm{N}=261) \\
0,648^{* * *}\end{array}$} \\
\hline $\mathrm{H}_{1}(\mathrm{a}-\mathrm{b})$ & $\mathrm{BA} \rightarrow \mathrm{BI}$ & & \\
\hline $\mathrm{H}_{2}(\mathrm{a}-\mathrm{b})$ & $\mathrm{BA} \rightarrow \mathrm{BL}$ & $0,339^{* *}$ & 0,004 (n.s.) \\
\hline $\mathrm{H}_{3}(\mathbf{a}-\mathrm{b})$ & $\mathrm{BI} \rightarrow \mathrm{SAT}$ & $0,613^{* * *}$ & $0,527^{* * *}$ \\
\hline $\mathrm{H}_{4}(\mathbf{a}-\mathrm{b})$ & $\mathrm{BI} \rightarrow \mathrm{BL}$ & 0,262 (n.s.) & $0,294^{*}$ \\
\hline $\mathrm{H}_{5}(\mathbf{a}-\mathrm{b})$ & $\mathrm{BI} \rightarrow \mathrm{PI}$ & $0,299^{* * *}$ & 0,086 (n.s.) \\
\hline $\mathrm{H}_{6}(\mathrm{a}-\mathrm{b})$ & $\mathrm{SAT} \rightarrow \mathrm{BL}$ & 0,064 (n.s.) & 0,124 (n.s.) \\
\hline $\mathrm{H}_{7}(\mathrm{a}-\mathrm{b})$ & $\mathrm{SAT} \rightarrow \mathrm{WOM}$ & $0,213^{* *}$ & $0,223^{* * *}$ \\
\hline $\mathrm{H}_{8}(\mathbf{a}-\mathbf{b})$ & $\mathrm{SAT} \rightarrow \mathrm{PI}$ & 0,040 (n.s.) & 0,062 (n.s.) \\
\hline $\mathrm{H}_{9}(\mathrm{a}-\mathrm{b})$ & $\mathrm{BL} \rightarrow \mathrm{WOM}$ & $0,772^{* * *}$ & $0,767^{* * *}$ \\
\hline $\mathrm{H}_{10}(\mathrm{a}-\mathrm{b})$ & $\mathrm{BL} \rightarrow \mathrm{PI}$ & $0,530^{* * *}$ & $0,587^{* * *}$ \\
\hline $\mathrm{H}_{11}(\mathrm{a}-\mathrm{b})$ & $\mathrm{WOM} \rightarrow \mathrm{PI}$ & 0,059 (n.s.) & 0,140 (n.s.) \\
\hline Examinin & otheses for females and males & $\mathrm{H}_{1 \mathrm{a}}-\ldots-\mathrm{H}_{11 \mathrm{a}}$ & $\mathrm{H}_{1 \mathrm{~b}}-\ldots-\mathrm{H}_{11 \mathrm{~b}}$ \\
\hline \multicolumn{4}{|c|}{ Explained Variance } \\
\hline Brand Im & & $\% 60$ & $\% 42$ \\
\hline Customer & faction & $\% 38$ & $\% 28$ \\
\hline Brand Lo & & $\% 37$ & $\% 14$ \\
\hline WOM & & $\% 77$ & $\% 73$ \\
\hline Purchase & tion & $\% 66$ & $\% 59$ \\
\hline
\end{tabular}

Note: 1-Acronyms: $\mathbf{B A}=$ Brand Awareness; $\mathbf{B I}=$ Brand Image; $\mathbf{S A T}=$ Satisfaction; $\mathbf{B L}=$ Brand Loyalty; WOM=Word of Mouth (WOM) PI:= Purchase Intention. $2-{ }^{* * *} p<0.001, \quad{ }^{* *} p<0.010,{ }^{*} p<0.050$ 3- n.s.: not significant

The results of multi-group sem analysis were interpreted separately for each hypothesis. Regarding this analysis, brand awareness significantly affects the brand image of both females and males. At the same time, the effect of brand awareness on brand loyalty is significant in females and not significant in males. Likewise, the effect of brand image on customer satisfaction is significant for both females and males. However, the effect of brand image on brand loyalty is significant for males and not significant for females. Also, the effect of brand image on purchase intention is significant in females and not significant in males. For both females and males, the impact of customer satisfaction on brand loyalty and purchase intention is not significant, but the effect of customer satisfaction on WOM is significant. Finally, the impact of brand loyalty on WOM and purchase intention is significant for both genders, but WOM's impact on purchase intention is not significant for both males and females.

Another important comment is how the variance rates of the variables in the model change according to gender. Accordingly, the model's applicability to real life is more likely for women. Regarding females, the variance explanation rate of brand image is $60 \%$, brand loyalty is $37 \%$, WOM is $77 \%$, and purchase intention is $66 \%$. On the other hand, in terms of explained variance rates, brand image was $42 \%$, brand loyalty was $14 \%$, WOM was $73 \%$, and purchase intent was $59 \%$ for males.

\section{Discussion}

When the study's findings were examined, it was found that brand awareness had a significant direct effect on brand image. These findings are consistent with the study by Barreda et al. (2016) ve Martínez et al. (2009). Also, the impact of gender was determined that this relationship was significant for both males and females. Therefore, it is determined that brand awareness does not directly affect brand loyalty. These findings are different from the study by Kim et al. (2018) and Torres et al. (2015), but they are consistent with the study by Im, Kim, Elliot \& Han (2012). However, when the indirect effect of brand awareness on brand loyalty through brand image is analyzed, this effect is significant. Besides, when the effect of gender was examined, it was found that the direct effect of brand awareness on brand 
loyalty was significant in females and not significant in males. The indirect effect of brand awareness on the purchase intention through brand image was also significant. Regarding this effect, Lee (2014: 1245) stated that brand awareness and brand image signify how consumers perceive the brand and can be used to predict purchasing behaviour. Also, according to Torres et al. (2015), although awareness does not always affect the purchase intention, it can increase brand-related preferences. Since the indirect effect of brand awareness on WOM and purchase intent through brand loyalty seems to be not significant, it can be stated that the findings obtained are consistent with the literature.

Another variable used in the study is brand image, and the effects of brand image on satisfaction, brand loyalty and purchase intention were found to be significant. These findings are consistent with the studies conducted by Song et al. (2019), Wai Lai (2019), Kim et al. (2018), Cretu \& Brodie (2007: 233), Mody et al. (2017), Martínez et al. (2009), Lee (2014: 1245) and Im et al. (2012). Also, the indirect effects of brand image on brand loyalty, WOM and purchase intention were examined. According to this analysis, although the brand image directly affects brand loyalty and purchase intention, the indirect effect that occurs through satisfaction is not significant. However, in the case of the mediating effect of customer satisfaction, the brand image shows a significant effect on the WOM. Therefore, the indirect impact of brand image on WOM and purchase intention through brand loyalty is significant, and the findings are similar to the literature. Thus, the brand image plays a critical role in understanding the purchasing behaviour of consumers and positioning the brand (cited by Im et al., 2012: 399). Also, considering the effect of gender on these paths, the effect of brand image on customer satisfaction is significant for both genders. However, the impact of brand image on brand loyalty is satisfaction for males, and the effect on purchase intention is satisfaction for females.

Customer satisfaction did not significantly affect brand loyalty and purchase intention. However, the effect of customer satisfaction on WOM was significant. Also, customer satisfaction on WOM and purchase intention through brand loyalty and its indirect impact on WOM were not significant. As a result, these findings are not consistent with the studies conducted by Nam et al. (2011), Song et al. (2019), Hew et al. (2016), Bai et al. (2008) ve Gamboa \& Gonçalves (2014: 713). However, they are consistent with the studies by Verkijika \& De Wet (2019), Konuk (2019) and Ranaweera \& Jayawardhena (2014). In addition, the findings obtained in terms of gender were the same with direct and indirect effects.

In terms of brand loyalty, it had a significant direct impact on WOM and purchase intention. However, the indirect impact of brand loyalty on the purchase intention through WOM was not significant. Findings obtained indirect effect are similar to the literature (Kim \& Lee, 2019; Das, 2014; Anderson, Knight, Pookulangara \& Josiam, 2014; Munnukka et al., 2015; Eelen, Özturan \& Verlegh, 2017; Huang \& Chen, 2018).

The last variable used in the analysis in the model is WOM, and the direct effect of WOM on purchasing intention was not significant. In terms of the gender variable, the results of this relationship are similar to the immediate impact. However, these findings differed from the literature (Chiu et al., 2016; Tajvidi \& Karami, 2017: 1). The study conducted by Chiu et al. (2016) was about the airline sector, and the study conducted by Tajvidi \& Karami (2017) was about the hospitality sector. It is considered that the results that differ from the literature are ordinary because the consumers following the brands on social media are examined. Because social media is not the place where the comments about brands are read, it is an environment where the shares of consumers and brands are followed. The first purpose of the consumers who follow the brands on social media is not to read the consumer comments to buy the brand they follow but to get information and enjoy the experience from the sharings.

While the explained variance rates in the model were low for customer satisfaction and brand loyalty, it was high in terms of brand image, WOM and purchase intention. Social media significantly affects WOM and purchasing intent and greatly influences brand image. Therefore, the explained variance rate related to brand image, WOM, and purchase intention was expected to be high. However, the described variance rate of brand loyalty and customer satisfaction was low. In this regard, although loyalty provides a significant competitive advantage, it may be challenging to create loyalty due to the conveniences provided by the internet or social media to other businesses and being a click away from consumers (Kwon \& Lennon, 2009: 559). Besides, the study conducted by Büyükdağ and Kitapci (2017) found that the relationship between e-satisfaction and e-loyalty was weaker among consumers who used the internet more.

Finally, it is examined whether the model differs in terms of gender. In this regard, it was observed that the explained variance rates of the variables differed, and the explained variance rate of all variables in the model was higher in females. Unfortunately, the results could not be discussed because there is no similar study in the literature involving gender. However, peer recommendation has a more substantial 
impact on women's attitudes compared to men in online medium or on social media \{Formatting Citation\}. Also, females have more vital emotional connectedness than males in social media (Ertugan, 2016). According to this situation, the findings are consistent with the literature.

\section{Conclusion}

Customers actively use social media, which creates important opportunities for brands. This study investigated the effects of the promotion activities related to brand awareness and brand image on the marketing variables (customer satisfaction, brand loyalty, WOM and purchase intention). The first result of the study; brand awareness directly affects the brand image and indirectly affects customer satisfaction, brand loyalty and purchase intention. The second result is that brand image is considered crucial for brands followed on social media, and it directly affects customer satisfaction, brand loyalty, and purchase intention and indirectly WOM. The third result is that customer satisfaction significantly affects WOM. The fourth result of the study is that brand loyalty directly impacts WOM and purchase intention. The fifth result is that the effect of WOM on purchase intention is not significant. Also, the final result is that the explained variance rates of the variables and regression coefficient of the paths differ in terms of gender categories in the model.

\section{Managerial implication}

All brands actively use social media channels. Therefore, managerial implications obtained from this study will provide significant benefits to businesses. The first of these implications is that brand awareness is important, and brand awareness should be created with low-cost social media ads. According to Barreda et al. (2015: 601), brand awareness is the essential element of the communication process and effectively creates positive brand perception (Im et al., 2012: 392). It was also stated that consumers familiar with the brand had a higher purchase intention than non-familiar consumers (Martins et al., 2019: 381).

The second managerial implication is that brand image is vital for brands on social media. Because, according to the results of the analysis, the brand image shows important effects on essential marketing variables such as customer satisfaction, brand loyalty, WOM and purchase intention. In the study by Keller (1993), the concepts required for the brand image were emphasized. Accordingly, to increase the brand image of the managers, the brand associations conveyed through social media should be unique only to a particular brand (uniqueness) and create a strong impression. In addition, the brand image that is tried to be made should be congruent with the brand because a unique and strong brand image plays a vital role in decisions that require high participation for consumers (Keller, 1993: 3). The promotional activities suggested for the brand associations should influence the customers' attitudes. Also, the brand image should include the functional, symbolic and experiential benefits proposed by the brand, and practical and experiential benefits should be used to present the brand image to customers through social media. Differentiating perceptions of price, packaging, usage image and user image that are not related to the product for customers is suggested to create a positive brand image because social media plays a vital role in the success of brands in terms of luxury products (Godey et al., 2016: 5834). Consumers also regard their pleasure and the status symbol of the product in terms of purchase intention (Godey et al., 2016: 5835). Brands on social media should also shape consumers' perceptions through brand image because consumers follow brands that express themselves and will see a positive reaction by other people.

The third managerial implication is that businesses should build brand loyalty in customers. Because in this study, we saw that brand loyalty plays a critical role in terms of both WOM and purchase intention. However, we have found that brand loyalty has a low explained variance rate. We think the reason for this is that customers who follow the brands in online environments or social media may have the possibility of tending to different alternatives or following other brands. However, loyal customers reach the brand in their minds more quickly than non-loyal customers (Eelen et al., 2017: 874). This situation shows us that businesses need to pay attention to brand loyalty programs and gain a place in the minds of consumers to create brand loyalty. Another important factor emerging in brand loyalty is the robust embedding of brand information (brand awareness and brand image) in consumers' minds.

The final managerial implication is that the gender variable has significant marketing variables. Here, a strategy can be developed on different variables regarding brands positioned based on gender. For example, it is important to focus on brand awareness and brand image to create brand loyalty for females. In this case, brand loyalty will be strengthened, and significant gains will be achieved for brands in WOM and purchase intention. On the other hand, in terms of brands positioned according to men, it is determined that brand awareness on social media has no direct effect on brand loyalty. Therefore, if the brand is strengthened with the brand image, it is thought that it will gain significant 
gains in terms of brand loyalty and may have significant effects on the marketing variables (WOM and intention to purchase).

\section{Theoretical implication}

According to Ward (1974), the socialization of consumers is defined as the knowledge, skills and attitudes that young people gain to be a consumer in the market (cited by Chu \& Sung, 2015: 253). On the other hand, social media provides an important opportunity for consumers to socialize, and it is an important medium that can also be evaluated for brands. Because the socialization process of consumers is based on social learning theory (cited by Chu \& Sung, 2015: 253), the socialization process of consumers can provide a framework to understand how consumers' cognitions, attitudes, social roles and behaviours develop, and accordingly, individuals can create attitudinal and behavioural patterns by learning and interacting through socializing agents (Chu \& Sung, 2015: 253). According to Chu and Sung (2015: 253), in social learning theory, peers and family are emphasized as the external source of socialization and helpful in learning consumption roles. In terms of this study, it is thought that brand awareness and brand image stand out in social learning theory. Because individuals are open to learning about individuals or objects, they consider them valuable. Therefore, obtaining information about the brand is one of the most important primary stages of the consumer learning process. Furthermore, according to associative network theory, brand image is a mental scheme used to establish a connection between network nodes through associations. Positive or negative new information can cause changes in the mental scheme (cited by Martínez Salinas \& Pina Pérez, 2009: 51). Therefore, it is seen that brand awareness is important in terms of associative network theory.

The brand image is essential for consumers who follow brands on social media, and another concept that arises here is conspicuous consumption. Brands valued by consumers and accepted by consumers' social environment are followed, even if they are consumed or not consumed by consumers. Here, it is considered that it is crucial to have a high brand image in terms of conspicuous consumption theory. Also, according to Social comparison theory, people tend to follow the ideas of the majority of group members who use luxury brands (Ko, Costello \& Taylor, 2019: 406). As a result, it is thought that social comparison theory can help to understand whether brands with a high image are liked or followed by consumers in social media.

Following the brands on social media can extend consumers' self. This situation can be supported by the extended self-theory proposed by Belk (1988). Also, Social impact theory explains how individuals affect one another or are affected by each other (Chang, Zhu, Wang \& Li, 2018: 283). Brands on social media also try to influence consumers and emphasise important aspects through brand awareness and image. The social presence theory is one of the theories that can explain consumers' behaviour in virtual social environments. Also, the subjective nature of the virtual environment makes the interactions more eye-catching and social, and the increase in this social presence makes it possible to increase the brand engagement practices for the brands on social media (Osei-Frimpong \& McLean, 2018: 11).

\section{Limitation and suggestion}

The first limitation of the research is that the study is not generalizable because the sampling method used is the convenience sampling method. Therefore, new studies can be done by applying random samples in future studies. The second limitation is the application of the sample to the Y generation, and the results obtained from this study are related to the $Y$ generation. However, due to the widespread use of social media, generation $\mathrm{X}$ has also started to use social media. Therefore, it is recommended to use the generation $X$ sample in future studies. Also, the findings of this research are limited to consumers who follow brands on social media. Although many consumers who follow brands on social media have reached huge numbers, it does not represent all populations. Another limitation is that this study represents specific geography. Therefore, performing similar studies in different countries or regions may increase the representation ability of this study. Finally, this study expresses a model for collectivist societies. Therefore, similar studies in individual cultures will allow the in-depth learning of the relationships between brand and marketing variables for consumers following social media.

\section{Peer-review:}

Externally peer-reviewed

\section{Conflict of interests:}

The author has no conflict of interest to declare.

\section{Grant Support:}

The author declared that this study has received no financial support. 


\section{References}

Abzari, M., Ghassemi, R. A., \& Vosta, L. N. (2014). Analysing the Effect of Social Media on Brand Attitude and Purchase Intention: The Case of Iran Khodro Company. Procedia - Social and Behavioral Sciences, 143, 822-826. https:// doi.org/10.1016/j.sbspro.2014.07.483

Agnihotri, R., Dingus, R., Hu, M. Y., \& Krush, M. T. (2013). Social media: Influencing customer satisfaction in B2B sales. Industrial Marketing Management, 53, 172-180. https://doi.org/10.1016/j.indmarman.2015.09.003

Ahmad, S. N., \& Laroche, M. (2017). Analyzing electronic word of mouth: A social commerce construct. International Journal of Information Management, 37(3), 202-213. https://doi.org/10.1016/j.ijinfomgt.2016.08.004

Anderson, K. C., Knight, D. K., Pookulangara, S., \& Josiam, B. (2014). Influence of hedonic and utilitarian motivations on retailer loyalty and purchase intention: A facebook perspective. Journal of Retailing and Consumer Services, 21(5), 773-779. https:// doi.org/10.1016/j.jretconser.2014.05.007

Babin, B. J., Borges, A., \& James, K. (2016). The role of retail price image in a multi-country context: France and the USA. Journal of Business Research, 69(3), 1074-1081. https:// doi.org/10.1016/j.jbusres.2015.08.023

Bachleda, C., Fakhar, A., \& Elouazzani, Z. (2016). Quantifying the effect of sponsor awareness and image on the sports involvement-purchase intention relationship. Sport Management Review, 19(3), 293-305. https://doi.org/10.1016/j.smr.2015.08.001

Bai, B., Law, R., \& Wen, I. (2008). The impact of website quality on customer satisfaction and purchase intentions : Evidence from Chinese online visitors. International Journal of Hospitality Management, 27, 391-402. https://doi.org/10.1016/j.ijhm.2007.10.008

Barreda, A. A., Bilgihan, A., Nusair, K., \& Okumus, F. (2015). Generating brand awareness in Online Social Networks. Computers in Human Behavior, 50, 600-609. https://doi.org/10.1016/j.chb.2015.03.023

Barreda, A. A., Bilgihan, A., Nusair, K., \& Okumus, F. (2016). Online branding: Development of hotel branding through interactivity theory. Tourism Management, 57, 180-192. https://doi.org/10.1016/j.tourman.2016.06.007

Baum, D., Spann, M., Füller, J., \& Thürridl, C. (2019). The impact of social media campaigns on the success of new product introductions. Journal of Retailing and Consumer Services, 50(July 2018), 289297. https://doi.org/10.1016/j.jretconser.2018.07.003

Belk, R. (1988). Possessions and the Extended Self. Journal of Consumer Research, 15(2), 139-168. https://doi.org/10.1086/209154

Büyükdağ, N., Kaya, A., \& Kitapci, O. (2019). The Effect of Marketing Expenditures on Business Performance: Time Series Analysis on Causality. Journal of Applied Economics and Business Research, 9(4), 197-211.

Büyükdağ, N., \& Kitapci, O. (2017). Does The E-Loyalty Increase As The Consumer s Access To The Internet Increases An Empirical Study In Turkey. Journal of Business Research - Turk, 9(4), 139-154. https://doi.org/10.20491/isarder.2017.325

Büyükdağ, N., Soysal, A. N., \& Kitapci, O. (2020). The effect of specific discount pattern in terms of price promotions on perceived price attractiveness and purchase intention: An experimental research. Journal of Retailing and Consumer Services, 55(February). https://doi.org/10.1016/j.jretconser.2020.102112

Calabrese, A., Costa, R., \& Rosati, F. (2016). Gender differences in customer expectations and perceptions of corporate social responsibility. Journal of Cleaner Production, 116, 135-149. https://doi.org/10.1016/j.jclepro.2015.12.100

Chang, J. H., Zhu, Y. Q., Wang, S. H., \& Li, Y. J. (2018). Would you change your mind? An empirical study of social impact theory on Facebook. Telematics and Informatics, 35(1), 282-292. https://doi.org/10.1016/j.tele.2017.11.009

Chen, S. C. (2012). The customer satisfaction-loyalty relation in an interactive e-service setting: The mediators. Journal of Retailing and Consumer Services, 19(2), 202-210. https://doi.org/10.1016/j.jretconser.2012.01.001 
Cheng, F.-F., Wu, C.-S., \& Chen, Y.-C. (2018). Creating customer loyalty in online brand communities. Computers in Human Behavior, 105752. https:/ / doi.org/10.1016/j.chb.2018.10.018

Chiu, S. C., Liu, C. H., \& Tu, J. H. (2016). The influence of tourists' expectations on purchase intention: Linking marketing strategy for low-cost airlines. Journal of Air Transport Management, 53, $226-234$. https://doi.org/10.1016/j.jairtraman.2016.03.010

Chu, S. C., \& Sung, Y. (2015). Using a consumer socialization framework to understand electronic wordof-mouth (eWOM) group membership among brand followers on Twitter. Electronic Commerce Research and Applications, 14(4), 251-260. https://doi.org/10.1016/j.elerap.2015.04.002

Coelho, P. S., Rita, P., \& Santos, Z. R. (2018). On the relationship between consumer-brand identification, brand community, and brand loyalty. Journal of Retailing and Consumer Services, 43(February), 101110. https://doi.org/10.1016/j.jretconser.2018.03.011

Cretu, A. E., \& Brodie, R. J. (2007). The influence of brand image and company reputation where manufacturers market to small firms: A customer value perspective. Industrial Marketing Management, 36(2), 230-240. https:/ / doi.org/10.1016/j.indmarman.2005.08.013

Das, G. (2014a). Linkages of retailer awareness, retailer association, retailer perceived quality and retailer loyalty with purchase intention: A study of Indian food retail brands. Journal of Retailing and Consumer Services, 21(3), 284-292. https:/ / doi.org/10.1016/j.jretconser.2014.02.005

Das, G. (2014b). Linkages of retailer personality, perceived quality and purchase intention with retailer loyalty: A study of Indian non-food retailing. Journal of Retailing and Consumer Services, 21(3), 407414. https://doi.org/10.1016/j.jretconser.2013.11.001

Demangeot, C., \& Broderick, A. J. (2010). Consumer Perceptions of Online Shopping Environments. Psychology \& Marketing, 30(6), 461-469. https:/ / doi.org/10.1002/mar

Digital 2020 Report. (2020). Digital 2020 Report. In We Are Social $\mathcal{E}$ Hootsuite. https://doi.org/https://datareportal.com/reports/digital-2020-global-digital-overview

Eelen, J., Özturan, P., \& Verlegh, P. W. J. (2017). The differential impact of brand loyalty on traditional and online word of mouth: The moderating roles of self-brand connection and the desire to help the brand. International Journal of Research in Marketing, 34(4), 872-891. https://doi.org/10.1016/j.ijresmar.2017.08.002

Erkan, I., \& Evans, C. (2016). The influence of eWOM in social media on consumers' purchase intentions: An extended approach to information adoption. Computers in Human Behavior, 61, 47-55. https://doi.org/10.1016/j.chb.2016.03.003

Ertugan, A. (2016). Using Statistical Reasoning Techniques for Measuring Users' Emotional Connectedness to Facebook and their Attitudes Towards Facebook Advertising. Procedia Computer Science, 102(August), 677-682. https://doi.org/10.1016/j.procs.2016.09.461

Feng, J., \& Papatla, P. (2011). Advertising: Stimulant or Suppressant of Online Word of Mouth? Journal of Interactive Marketing, 25(2), 75-84. https:/ / doi.org/10.1016/j.intmar.2010.11.002

Fornell, C., \& Larcker, D. F. (1981). Evaluating Structural Equation Models with Unobservable Variables and Measurement Error. Journal of Marketing Research, 18(Şubat), 39-50.

Foroudi, P., Jin, Z., Gupta, S., Foroudi, M. M., \& Kitchen, P. J. (2018). Perceptional components of brand equity: Configuring the Symmetrical and Asymmetrical Paths to brand loyalty and brand purchase intention. Journal of Business Research, 89(January), 462-474. https://doi.org/10.1016/j.jbusres.2018.01.031

Gamboa, A. M., \& Gonçalves, H. M. (2014). Customer loyalty through social networks: Lessons from Zara on Facebook. Business Horizons, 57(6), 709-717. https:/ / doi.org/10.1016/j.bushor.2014.07.003

Gaskin, J., \& Lim, J. (2016). Confirmatory Factor Analysis - StatWiki. http:/ / statwiki.kolobkreations.com/index.php?title=Confirmatory_Factor_Analysis

Gensler, S., Völckner, F., Liu-Thompkins, Y., \& Wiertz, C. (2013). Managing brands in the social media environment. Journal of Interactive Marketing, 242-256. https://doi.org/10.1016/j.intmar.2013.09.004

Godey, B., Manthiou, A., Pederzoli, D., Rokka, J., Aiello, G., Donvito, R., \& Singh, R. (2016). Social media marketing efforts of luxury brands: Influence on brand equity and consumer behavior. Journal of Business Research, 69(12), 5833-5841. https://doi.org/10.1016/j.jbusres.2016.04.181 
Habibi, M. R., Laroche, M., \& Richard, M. O. (2014). The roles of brand community and community engagement in building brand trust on social media. Computers in Human Behavior, 37, 152-161. https://doi.org/10.1016/j.chb.2014.04.016

Hair, J. F., Black, W. C., Babin, B. J., \& Anderson, R. E. (2014). Multivariate Data Analysis. In Pearson Prentice Hall (p. 816). https:/ / doi.org/10.1016/j.ijpharm.2011.02.019

Han, H., Nguyen, H. N., Song, H., Chua, B. L., Lee, S., \& Kim, W. (2018). Drivers of brand loyalty in the chain coffee shop industry. International Journal of Hospitality Management, 72(January 2017), 86-97. https://doi.org/10.1016/j.ijhm.2017.12.011

Han, H., Yu, J., \& Kim, W. (2019). Investigating airline customers' decision-making process for emerging environmentally-responsible electric airplanes: Influence of gender and age. Tourism Management Perspectives, 31(March), 85-94. https:/ / doi.org/10.1016/j.tmp.2019.03.013

Hew, J. J., Lee, V. H., Ooi, K. B., \& Lin, B. (2016). Mobile social commerce: The booster for brand loyalty? Computers in Human Behavior, 59, 142-154. https:/ / doi.org/10.1016/j.chb.2016.01.027

Hsu, C. L., Chang, C. Y., \& Yansritakul, C. (2017). Exploring purchase intention of green skincare products using the theory of planned behavior: Testing the moderating effects of country of origin and price sensitivity. Journal of Retailing and Consumer Services, 34(August 2016), 145-152. https://doi.org/10.1016/j.jretconser.2016.10.006

Hu, L., \& Bentler, P. M. (1999). Cutoff criteria for fit indexes in covariance structure analysis: Conventional criteria versus new alternatives. Structural Equation Modeling: A Multidisciplinary Journal, 6(1), 1-55. https:/ / doi.org/10.1080/10705519909540118

Huang, S. L., \& Chen, C. T. (2018). How consumers become loyal fans on Facebook. Computers in Human Behavior, 82, 124-135. https:// doi.org/10.1016/j.chb.2018.01.006

Huang, X., \& Ge, J. (2019). Electric vehicle development in Beijing: An analysis of consumer purchase intention. Journal of Cleaner Production, 216, 361-372. https:/ / doi.org/10.1016/j.jclepro.2019.01.231

Hudson, S., Huang, L., Roth, M. S., \& Madden, T. J. (2016). The influence of social media interactions on consumer-brand relationships: A three-country study of brand perceptions and marketing behaviors. International Journal of Research in Marketing, 33(1), 27-41. https://doi.org/10.1016/j.ijresmar.2015.06.004

Im, H. H., Kim, S. S., Elliot, S., \& Han, H. (2012). Conceptualizing Destination Brand Equity Dimensions from a Consumer-Based Brand Equity Perspective. Journal of Travel E Tourism Marketing, 29(4), 385403. https://doi.org/10.1080/10548408.2012.674884

Keller, K. L. (1993a). Conceptualizing, Measuring, and Managing Customer-Based Brand Equity. Journal of Marketing, 57(1), 1-22.

Keller, K. L. (1993b). Conceptualizing, Measuring, Managing Customer-Based Brand Equity. Journal of Marketing, 57(1), 1-22. https://doi.org/10.2307/1252054

Kim, A. J., \& Ko, E. (2012). Do social media marketing activities enhance customer equity? An empirical study of luxury fashion brand. Journal of Business Research, 65(10), 1480-1486. https:// doi.org/10.1016/j.jbusres.2011.10.014

Kim, Junghun, Lee, H., \& Lee, J. (2020). Smartphone preferences and brand loyalty: A discrete choice model reflecting the reference point and peer effect. Journal of Retailing and Consumer Services, 52(May 2019), 101907. https:/ / doi.org/10.1016/j.jretconser.2019.101907

Kim, Juran, \& Lee, K. H. (2019). Influence of integration on interactivity in social media luxury brand communities. Journal of Business Research, 99(October 2017), 422-429. https:// doi.org/10.1016/j.jbusres.2017.10.001

Kim, S. (Sam), Choe, J. Y. (Jacey), \& Petrick, J. F. (2018). The effect of celebrity on brand awareness, perceived quality, brand image, brand loyalty, and destination attachment to a literary festival. Journal of Destination Marketing and Management, 9(April), 320-329. https://doi.org/10.1016/j.jdmm.2018.03.006

Kim, S., Koh, Y., Cha, J., \& Lee, S. (2015). Effects of social media on firm value for U.S. restaurant companies. International Journal of Hospitality Management, 49, 40-46. https://doi.org/10.1016/j.ijhm.2015.05.006

Kim, W. H., Cho, J. L., \& Kim, K. S. (2019). The relationships of wine promotion, customer satisfaction, 
and behavioral intention: The moderating roles of customers' gender and age. Journal of Hospitality and Tourism Management, 39(January), 212-218. https://doi.org/10.1016/j.jhtm.2019.03.001

Ko, E., Costello, J. P., \& Taylor, C. R. (2019). What is a luxury brand? A new definition and review of the literature. Journal of Business Research, 99(August 2017), 405-413. https://doi.org/10.1016/j.jbusres.2017.08.023

Konuk, F. A. (2019). The influence of perceived food quality, price fairness, perceived value and satisfaction on customers' revisit and word-of-mouth intentions towards organic food restaurants. Journal of Retailing and Consumer Services, 50(February), 103-110. https://doi.org/10.1016/j.jretconser.2019.05.005

Kotler, P., \& Keller, K. L. (2008). Marketing Management (13th editi). Prentice Hall.

Kudeshia, C., Sikdar, P., \& Mittal, A. (2016). Spreading love through fan page liking: A perspective on small scale entrepreneurs. Computers in Human Behavior, 54, 257-270. https://doi.org/10.1016/j.chb.2015.08.003

Kwon, W. S., \& Lennon, S. J. (2009). What induces online loyalty? Online versus offline brand images. Journal of Business Research, 62(5), 557-564. https:/ / doi.org/10.1016/j.jbusres.2008.06.015

Kwun, D. J. W. (2011). Effects of campus foodservice attributes on perceived value, satisfaction, and consumer attitude: A gender-difference approach. International Journal of Hospitality Management, 30(2), 252-261. https://doi.org/10.1016/j.ijhm.2010.09.001

Laroche, M., Habibi, M. R., \& Richard, M. (2013a). International Journal of Information Management To be or not to be in social media: How brand loyalty is affected by social media? International Journal of Information Management, 33(1), 76-82. https:// doi.org/10.1016/j.ijinfomgt.2012.07.003

Laroche, M., Habibi, M. R., \& Richard, M. O. (2013b). To be or not to be in social media: How brand loyalty is affected by social media? International Journal of Information Management, 33(1), 76-82. https:// doi.org/10.1016/j.ijinfomgt.2012.07.003

Lee, C. J. (2014). Effects of sport mega-events on city brand awareness and image: Using the 2009 world games in Kaohsiung as an example. Quality and Quantity, 48(3), 1243-1256. https://doi.org/10.1007/s11135-013-9832-6

Lee, K. Y., \& Choi, H. (2019). Predictors of electronic word-of-mouth behavior on social networking sites in the United States and Korea: Cultural and social relationship variables. Computers in Human Behavior, 94(December 2018), 9-18. https:// doi.org/10.1016/j.chb.2018.12.025

Lien, C. H., Wen, M. J., Huang, L. C., \& Wu, K. L. (2015). Online hotel booking: The effects of brand image, price, trust and value on purchase intentions. Asia Pacific Management Review, 20(4), 210-218. https://doi.org/10.1016/j.apmrv.2015.03.005

Lin, J., Lobo, A., \& Leckie, C. (2017). The role of benefits and transparency in shaping consumers' green perceived value, self-brand connection and brand loyalty. Journal of Retailing and Consumer Services, 35(December 2016), 133-141. https:// doi.org/10.1016/j.jretconser.2016.12.011

Liu, Y. (2006). Word of Mouth for Movies : Its Dynamics and Impact on Box Office. Journal of Marketing, $70,74-89$.

Lu, A. C. C., Gursoy, D., \& Lu, C. Y. (2015). Authenticity perceptions, brand equity and brand choice intention: The case of ethnic restaurants. International Journal of Hospitality Management, 50, 36-45. https://doi.org/10.1016/j.ijhm.2015.07.008

Mangold, W. G., \& Faulds, D. J. (2009). Social media: The new hybrid element of the promotion mix. Business Horizons, 52(4), 357-365. https:// doi.org/10.1016/j.bushor.2009.03.002

Martínez, E., Montaner, T., \& Pina, J. M. (2009). Brand extension feedback: The role of advertising. Journal of Business Research, 62(3), 305-313. https://doi.org/10.1016/j.jbusres.2008.05.009

Martínez Salinas, E., \& Pina Pérez, J. M. (2009). Modeling the brand extensions' influence on brand image. Journal of Business Research, 62(1), 50-60. https:/ / doi.org/10.1016/j.jbusres.2008.01.006

Martins, J., Costa, C., Oliveira, T., Gonçalves, R., \& Branco, F. (2019). How smartphone advertising influences consumers' purchase intention. Journal of Business Research, 94(August 2017), 378-387. https://doi.org/10.1016/j.jbusres.2017.12.047

Mody, M., Day, J., Sydnor, S., Lehto, X., \& Jaffé, W. (2017). Integrating country and brand images: Using 
the product-Country image framework to understand travelers' loyalty towards responsible tourism operators. Tourism Management Perspectives, 24(May), 139-150. https://doi.org/10.1016/j.tmp.2017.08.001

Mortimer, G., \& Clarke, P. (2011). Supermarket consumers and gender differences relating to their perceived importance levels of store characteristics. Journal of Retailing and Consumer Services, 18(6), 575-585. https://doi.org/10.1016/j.jretconser.2011.08.007

Munnukka, J., Karjaluoto, H., \& Tikkanen, A. (2015). Are Facebook brand community members truly loyal to the brand? Computers in Human Behavior, 51(PA), 429-439. https://doi.org/10.1016/j.chb.2015.05.031

Murray, J., Elms, J., \& Teller, C. (2017). Examining the role of store design on consumers' cross-sectional perceptions of retail brand loyalty. Journal of Retailing and Consumer Services, 38(January), 147-156. https://doi.org/10.1016/j.jretconser.2017.06.001

Nadeem, W., Andreini, D., Salo, J., \& Laukkanen, T. (2015). Engaging consumers online through websites and social media: A gender study of Italian Generation Y clothing consumers. International Journal of Information Management, 35(4), 432-442. https:/ / doi.org/10.1016/j.ijinfomgt.2015.04.008

Nam, J., Ekinci, Y., \& Whyatt, G. (2011). Brand equity, brand loyalty and consumer satisfaction. Annals of Tourism Research, 38(3), 1009-1030. https://doi.org/10.1016/j.annals.2011.01.015

O'Cass, A., \& Carlson, J. (2012). An e-retailing assessment of perceived website-service innovativeness: Implications for website quality evaluations, trust, loyalty and word of mouth. Australasian Marketing Journal, 20(1), 28-36. https:// doi.org/10.1016/j.ausmj.2011.10.012

Osei-Frimpong, K., \& McLean, G. (2018). Examining online social brand engagement: A social presence theory perspective. Technological Forecasting and Social Change, 128(October 2017), 10-21. https://doi.org/10.1016/j.techfore.2017.10.010

Pappas, I. O., Pateli, A. G., Giannakos, M. N., \& Chrissikopoulos, V. (2014). Moderating effects of online shopping experience on customer satisfaction and repurchase intentions. International Journal of Retail $\mathcal{E}$ Distribution Management, 42(3), 187-204. https://doi.org/10.1108/IJRDM-03-2012-0034

Park, S. J., Lee, Y. R., \& Borle, S. (2018). The shape of Word-of-Mouth response function. Technological Forecasting and Social Change, 127(October 2017), 304-309. https://doi.org/10.1016/j.techfore.2017.10.006

Pereira, H. G., Salgueiro, M. de F., \& Rita, P. (2016). Online purchase determinants of loyalty: The mediating effect of satisfaction in tourism. Journal of Retailing and Consumer Services, 30, $279-291$. https://doi.org/10.1016/j.jretconser.2016.01.003

Persson, N. (2010). An exploratory investigation of the elements of B2B brand image and its relationship to price premium. Industrial Marketing Management, 39(8), 1269-1277. https://doi.org/10.1016/j.indmarman.2010.02.024

Podsakoff, P. M., MacKenzie, S. B., Lee, J. Y., \& Podsakoff, N. P. (2003). Common Method Biases in Behavioral Research: A Critical Review of the Literature and Recommended Remedies. Journal of Applied Psychology, 88(5), 879-903. https://doi.org/10.1037/0021-9010.88.5.879

Popp, B., \& Wilson, B. (2018). Investigating the role of identification for social networking Facebook brand pages. Computers in Human Behavior, 84, 141-152. https://doi.org/10.1016/j.chb.2018.01.033

Ranaweera, C., \& Jayawardhena, C. (2014). Talk up or criticize? Customer responses to WOM about competitors during social interactions. Journal of Business Research, 67(12), 2645-2656. https://doi.org/10.1016/j.jbusres.2014.04.002

Sääksjärvi, M., \& Samiee, S. (2011). Relationships among Brand Identity, Brand Image and Brand Preference: Differences between Cyber and Extension Retail Brands over Time. Journal of Interactive Marketing, 25(3), 169-177. https://doi.org/10.1016/j.intmar.2011.04.002

Seo, E. J., \& Park, J. W. (2018). A study on the effects of social media marketing activities on brand equity and customer response in the airline industry. Journal of Air Transport Management, 66(August 2017), 36-41. https://doi.org/10.1016/j.jairtraman.2017.09.014

Shanahan, T., Tran, T. P., \& Taylor, E. C. (2019). Getting to know you: Social media personalization as a means of enhancing brand loyalty and perceived quality. Journal of Retailing and Consumer Services, 47(January 2018), 57-65. https:/ / doi.org/10.1016/j.jretconser.2018.10.007 
Siqueira, J. R., Peña, N. G., ter Horst, E., \& Molina, G. (2019). Spreading the Word: How Customer Experience in a Traditional Retail Setting Influences Consumer Traditional and Electronic Word-ofmouth Intention. Electronic Commerce Research and Applications, 37(40), 100870. https://doi.org/10.1016/j.elerap.2019.100870

Song, H. J., Wang, J. H., \& Han, H. (2019). Effect of image, satisfaction, trust, love, and respect on loyalty formation for name-brand coffee shops. International Journal of Hospitality Management, 79(June 2018), 50-59. https://doi.org/10.1016/j.ijhm.2018.12.011

Sreen, N., Purbey, S., \& Sadarangani, P. (2018). Impact of culture, behavior and gender on green purchase intention. Journal of Retailing and Consumer Services, 41(December 2017), 177-189. https://doi.org/10.1016/j.jretconser.2017.12.002

Sürücü, Ö., Öztürk, Y., Okumus, F., \& Bilgihan, A. (2019). Brand awareness, image, physical quality and employee behavior as building blocks of customer-based brand equity: Consequences in the hotel context. Journal of Hospitality and Tourism Management, 40(July), 114-124. https://doi.org/10.1016/j.jhtm.2019.07.002

Tajvidi, R., \& Karami, A. (2017). The effect of social media on firm performance. Computers in Human Behavior, 105174, 1-10. https:/ / doi.org/10.1016/j.chb.2017.09.026

Tifferet, S., \& Vilnai-Yavetz, I. (2014). Gender differences in Facebook self-presentation: An international randomized study. Computers in Human Behavior, 35, 388-399. https://doi.org/10.1016/j.chb.2014.03.016

Torres, P. M., Augusto, M. G., \& Joao Verissimo Lisboa. (2015). Determining the causal relationships that affect consumer based brand equity-mediating effect of brand loyalty. Marketing Intelligence $\mathcal{E}$ Planning, 33(6), 944-956. https:// doi.org/10.1108/02634501011078138

Tran, G. A., \& Strutton, D. (2020). Comparing email and SNS users: Investigating e-servicescape, customer reviews, trust, loyalty and E-WOM. Journal of Retailing and Consumer Services, 53(101782). https://doi.org/10.1016/j.jretconser.2019.03.009

Tsiros, M., Mittal, V., \& Ross, W. T. (2004). The Role of Attributions in Customer Satisfaction: A Reexamination. Journal of Consumer Research, 31(2), 476-483. https://doi.org/10.1086/422124

Verkijika, S. F., \& De Wet, L. (2019). Understanding word-of-mouth (WOM) intentions of mobile app users: The role of simplicity and emotions during the first interaction. Telematics and Informatics, 41(May), 218-228. https:// doi.org/10.1016/j.tele.2019.05.003

Vicente-Molina, M. A., Fernández-Sainz, A., \& Izagirre-Olaizola, J. (2018). Does gender make a difference in pro-environmental behavior? The case of the Basque Country University students. Journal of Cleaner Production, 176, 89-98. https:/ / doi.org/10.1016/j.jclepro.2017.12.079

Wai Lai, I. K. (2019). Hotel image and reputation on building customer loyalty: An empirical study in Macau. Journal of Hospitality and Tourism Management, 38(September 2018), 111-121. https://doi.org/10.1016/j.jhtm.2019.01.003

Wakefield, L. T., \& Bennett, G. (2018). Sports fan experience: Electronic word-of-mouth in ephemeral social media. Sport Management Review, 21(2), 147-159. https:/ / doi.org/10.1016/j.smr.2017.06.003

$\mathrm{Wu}, \mathrm{C}$. W. (2016). The performance impact of social media in the chain store industry. Journal of Business Research. https:// doi.org/10.1016/j.jbusres.2016.04.130

Wu, P. C. S., Yeh, G. Y. Y., \& Hsiao, C. R. (2011). The effect of store image and service quality on brand image and purchase intention for private label brands. Australasian Marketing Journal, 19(1), 30-39. https://doi.org/10.1016/j.ausmj.2010.11.001

Yan, Q., Wu, S., Wang, L., Wu, P., Chen, H., \& Wei, G. (2016). E-WOM from e-commerce websites and social media: Which will consumers adopt? Electronic Commerce Research and Applications, 17, 62-73. https://doi.org/10.1016/j.elerap.2016.03.004 